\title{
PERAN KOMITE SEKOLAH SEBAGAI ADVISOR $Y$ AGENCY DALAM IMPLEMENTASI MANAJEMEN BERBASIS SEKOLAH DI SMA NEGERI 19 BONE
}

\author{
Andi Asasi Syam \\ St. Syamsudduha \\ Muhammad Khalifah Mustamin \\ Sekolah Menengah Atas Islam Athirah \\ Email: asasiyanti@gmail.com
}

\begin{abstract}
Abstrak: Tulisan ini akan mengurai tentang peran komite sekolah sebagai pemberi pertimbangan (advisory agency) dalam implementasi manajemen berbasis sekolah di SMA Negeri 19 Bone. Jenis penelitian ini adalah kualitatif yang dilaksanakan di SMA Negeri 19 Bone, yang terletak di Desa Masago Kecamatan Patimpeng Kabupaten Bone Provinsi Sulawesi Selatan. Pendekatan yang digunakan adalah pendekatan pedagogik, sosiologis, dan manajerial. Sumber data primer dalam penelitian ini adalah kepala sekolah, ketua komite, guru dan tenaga kependidikan sekolah, orang tua siswa dan masyarakat. Sedangkan data sekunder berupa dokumentasi penting menyangkut profil sekolah dan dokumen-dokumen yang berkaitan dengan penelitian. Pengumpulan data dilakukan dengan pengamatan, wawancara, cacatan lapangan, dan studi dokumentasi. Instrument yang digunakan oleh peneliti yaitu panduan observasi, pedoman wawancara, dan format catatan dokumentasi. Data diolah dan dianalisis dengan reduksi data, penyajian data, penarikan kesimpulan atau verifikasi. Keabsahan data diuji dengan triangulasi dan konfirmabilitas.

Hasil penelitian menunjukkan bahwa peran komite sekolah di SMA Negeri 19 Bone sebagai pemberi pertimbangan, berjalan sesuai dengan prosedur, dengan asumsi bahwa komite sekolah sebagai pemberi pertimbangan (advisory agency) dalam penentuan pelaksanaan kebijakan di satuan pendidikan melibatkan semua unsur, baik dari unsur sekolah ataupun dari luar sekolah seperti orang tua siswa dan masyarakat. Karena dari pelibatan semua unsur komite sekolah, orang tua siswa dan masyarakat akan sangat penting dalam peningkatan kualitas pendidikan di sekolah.
\end{abstract}

\section{Keywords: Komite Sekolah, Advisory Agency, Manajemen Berbasis Sekolah}

\section{PENDAHULUAN}

Manajemen pendidikan merupakan alternatif strategis untuk meningkatkan kualitas pendidikan, manajemen sekolah merupakan salah satu faktor yang mempengaruhi kualitas pendidikan, manajemen sekolah secara langsung akan mempengaruhi belajar, waktu mengajar dan proses pembelajaran ${ }^{1}$.

Pengembangan, peningkatan dan perbaikan pendidikan harus dilakukan secara holistik dan simultan, tidak boleh parsial walaupun mungkin dilakukan bertahap, perbaikan sektor kurikulum, tenaga guru dan fasilitas serta sarana pembelajaran, tidak

${ }^{1}$ E. Mulyasa, Manajemen Berbasis Sekolah Konsep Strategi dan Implementasi, (Bandung: Rosdakarya, 2005), h. 21-22. 
akan membawa perubahan signifikan jika tidak disertai dengan perbaikan pola dan kultur manajemen yang mendukung perubahan-perubahan tersebut.

Perubahan yang terjadi pada gilirannya akan mempengaruhi tata nilai kehidupan masyarakat yang mungkin sama sekali baru dan berbeda dengan gaya nilai yang sekarang dianut masyarakat, proses perubahan kesiapan lembaga-lembaga pendidikan dan institusi sosial lainnya menjadi sangat penting, sebab masyarakat yang berada pada proses transisi kultural sangat labil pada berbagai benturan nilai dan salah satunya adalah institusi sosial dan kultural yang diharapkan dapat berperan besar dalam mengatur irama perubahan tersebut adalah lembaga pendidikan ${ }^{2}$.

Pengaruh masyarakat terhadap sekolah sebagai lembaga sosial, terasa amat kuat, dan pengaruh pula kepada para individu yang ada dalam lingkungan sekolah, lingkungan di mana sekolah berada, merupakan masyarakat yang bersifat kompleks, terdiri dari berbagai macam tingkatan masyarakat yang saling melengkapi (over lapping), dan bersifat unik sebagai akibat latar belakang dimensi budaya yang beraneka ragam ${ }^{3}$.

Manajemen pendidikan nasional secara keseluruhan masih bersifat sentralistik sehingga kurang mendorong terjadinya demokratisasi dan desentralisasi penyelenggaraan pendidikan. Selain pemberian otonomi yang lebih besar pada sekolah dan pemerintah daerah dalam pengelolaan pendidikan, manajemen berbasis sekolah juga bertujuan mendorong pengambilan keputusan partisipatif yang melibatkan semua stakeholder pendidikan di sekolah, sehingga tercipta sense of belonging (rasa memiliki) dari mereka untuk mewujudkan pola baru manajemen pendidikan masa depan yang lebih bernuansa otonomi dan yang lebih demokratis, dan untuk meningkatkan peran serta masyarakat dalam bidang pendidikan, maka diperlukan wadah yang dapat mengakomodasi pandangan, aspirasi, dan yang mampu menggali potensi masyarakat untuk menjamin demokratisasi, transparansi dan akuntabilitas pendidikan. Wadah tersebut adalah dibentuknya dewan pendidikan di tingkat kabupaten/kota dan komite sekolah di tingkat satuan pendidikan.

Pemerintah melalui Departemen Pendidikan Nasional mengeluarkan Surat Keputusan Menteri Pendidikan Nasional No 044/4/2002 tanggal 2 April 2002 yang kini diperbaharui melalui Menteri Pendidikan dan Kebudayaan Republik Indonesia No 75 Tahun 2016 tentang Komite dan Dewan Sekolah. Keputusan tersebut merupakan payung hukum bagi pembentukan komite sekolah ditiap satuan sekolah secara nasional. Sebenarnya jika dilihat dari sejarah sekolahan, masyarakat telah berperan penting dalam upaya meningkatkan kualitas pendidikan antara lain dengan terbentuknya persatuan orang tua wali murid atau POMG, setelah itu mengalami peningkatan dengan dimunculkannya Badan Pembantu Penyelenggara Pendidikan (BP3) dan pada dekade yang sama dibentuk pula komite pendidikan di beberapa sekolah yang memiliki program khusus ${ }^{4}$.

Hal ini sesuai dengan konsep partisipasi berbasis masyarakat (community based participation) dan manajemen berbasis sekolah (school based management) yang kini

2Abdul Rochman Sholeh, Madrasah dan Pendidikan Anak Bangsa: Visi Misi dan Aksi (Jakarta: Raja Grafindo Persada, 2004), h. 129.

${ }^{3}$ Wahjosumidjo, Kepemimpinan Kepala Sekolah, Tinjauan Teoritik dan Permasalahannya, (Jakarta, Raja Grafindo Persada, 2002), h. 331

${ }^{4}$ Salladien, Komite Sekolah dan Kaitannya dengan Implementasi KBK.Makalah Seminar(7 Juli 2004). Fakultas MIPA ( Malang: Universitas Negeri Malang, 2004), h. 19. 
tidak hanya menjadi wacana tetapi mulai dilaksanakan di Indonesia ${ }^{5}$. Era reformasi telah membawa banyak perubahan kebijakan dasar di berbagai bidang kehidupan. Lahirnya UU No 22 tahun 1999 tentang Otonomi Daerah dan UU No 25 tahun 1999 tentang Perimbangan Keuangan Pusat dan Daerah membawa konsekuensi terhadap bidang-bidang kewenangan daerah sehingga lebih otonom termasuk di dalamnya pada bidang pendidikan. Keinginan pemerintah agar pengelolaan pendidikan di arahkan pada desentralisasi menuntut partisipasi masyarakat secara aktif untuk merealisasikan otonomi daerah. Otonomi pendidikan yang dikelolah, secara terpusat harus dirubah untuk mengikuti irama yang sedang berkembang sehingga otonomi daerah sebagai kebijakan politik di tingkat makro akan memberi imbas terhadap otonomi sekolah.

Kegiatan perencanaan pendidikan dan kegiatan pendidikan tidak pernah terlepas dari masyarakat sekitarnya, sebab ada hubungan saling memberi, saling mendukung dan saling menguntungkan antara lembaga pendidikan dan masyarakat ${ }^{6}$. Hal ini juga mengharapkan masyarakat agar ikut serta bertanggung jawab terhadap kemajuan dan kelancaran proses pendidikan dalam lembaga, sedangkan lembaga pendidikan juga diharapkan dapat bekerjasama secara erat dengan masyarakat. Konsekuensi dari hubungan tersebut adalah mengakomodasikan aspirasi, harapan dan kebutuhan stakeholder sekolah sehingga perlu dikembangkan suatu wadah untuk menampung dan menyalurkannya, yaitu didalam wadah komite sekolah.

Sri Wardiah, Murniati dan Djailani melalui hasil penelitiannya mengemukakan bahwa: Beberapa hal yang penting dilakukan oleh komite sekolah dalam upaya peningkatan mutu pendidikan, di antaranya adalah bekerja sama dengan berbagai masyarakat di sekitar sekolah dalam memperluas jaringan kerjasama antara pihak sekolah dan masyarakat yang berupa perlibatan masyarakat dalam pengambilan berbagai kebijakan untuk pengembangan sekolah. ${ }^{7}$

M. Misbah dalam penelitiannya mengatakan bahwa: Sebagai realisasi dari berbagai peran dan fungsi komite sekolah serta manifestasi dari system pendidikan yang demokratis, maka komite sekolah melakukan akuntabilitas public secara periodik kepada stakeholder. ${ }^{8}$

Erna Erviana Purnama Sari dari hasil penelitianya mengemukakan bahwa: Pihak sekolah dan komite sekolah harus saling berkomunikasi (communacation) baik secara langsung maupun lewat media dan saling memiliki rasa keterbukaan (transparan) untuk dapat menjalankan kegiatan dan program-program sekolah secara baik. $^{9}$

${ }^{5}$ E. Mulyasa, Manajemen Berbasis Sekolah, Konsep, Strategi, dan Implementasi, h. 15.

${ }^{6}$ M. pidarta, Perencanaan Pendidikan Partisipasi dengan Pendekatan Sistem, (Jakarta : Rineka Cipta, 1990), h. 18

${ }^{7}$ Sri wardiah, Murniati dan Djailani, 2014. Strategi Komite Sekolah Dalam Peningkatan Mutu

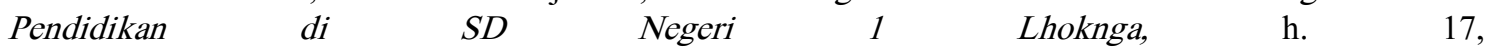
https://scholar.google.co.id/scholar?start=40\&q=jurnal+komite+sekolah\&hl=id\&as_sdt=0,5. Diakses: Senin, 20 November 2017.

${ }^{8}$ M. Misbah, Peran dan Fungsi Komite Sekolah Dalam Meningkatan Mutu Pendidikan, h. 13, https://scholar.google.co.id/scholar?start=40\&q=jurnal+komite+sekolah\&hl=id\&as_sdt=0,5. Diakses: Senin, 20 November 2017.

${ }^{9}$ Erna Avriana Purnama Sari, Peran Komite Sekolah Dalam Mendukung Peningkatan Mutu SD $\begin{array}{lllll}\text { Muhammadiyah } & \text { Wirobrajan } & 3 & \text { Yogyakarta, } & \text { h. }\end{array}$ https://scholar.google.co.id/scholar?start=40\&q=jurnal+komite+sekolah\&hl=id\&as_sdt=0,5. Diakses: Senin, 20 November 2017. 
Nora Silam and Hamdan Said said: The findings provide suggestions for reform of the existing SBM policy in Indonesia. It is suggested that the poilicy-makers who wanted to transform the educutaion system, can construct a policy that actually became an instrument to strenghen if it is clearly stated rights and authority for each stakeholder could lead to different and more positive outcomes in the context of school committee. ${ }^{10}$ (Nora Mislam dan Hamdan Said mengatakan bahwa: disarankan untuk reformasi kebijakan SBM yang ada di Indonesia. Bahwa pembuat kebijakan yang inigin mengubah sistem pendidikan, dapat membangun kebijakan yang benar-benar menjadi alat untuk memperkuat, jika jelas dinyatakan hak dan wewenang agar dapat mengarah pada hasil yang berbeda dan lebih positif dalam konteks komite sekolah.

Semenjak dikeluarkannya Surat Keputusan Menteri Pendidikan Nasional Nomor 044/U/2002 tentang dewan pendidikan dan komite sekolah, dapat dikatakan hampir semua sekolah telah memiliki komite sekolah yang mewakili masyarakat untuk mengakomodasi aspirasi, harapan dan kebutuhan stakeholder sekolah. Dalam UU No. 20 Tahun 2003 tentang Sistem Pendidikan Nasional disebutkan salah satu misi pendidikan adalah memberdayakan peranserta masyarakat dalam penyelenggaraan pendidikan berdasarkan prinsip otonomi daerah dalam konteks Negara Kesatuan Republik Indonesia (NKRI). Kemudian masyarakat berperan dalam peningkatan mutu pelayanan pendidikan yang meliputi perencanaan, pengawasan dan evaluasi program pendidikan melalui dewan pendidikan dan komite sekolah/madrasah. Komite sekolah merupakan badan mandiri yang mewadahi peran serta masyarakat dalam rangka meningkatkan mutu, pemerataan, dan efisiensi pengelolaan pendidikan di satuan pendidikan baik pada pendidikan prasekolah, jalur pendidikan Sekolah, maupun jalur pendidikan luar Sekolah. Komite Sekolah yang berkedudukan di setiap satuan pendidikan merupakan badan mandiri yang tidak memiliki hubungan hirarkis dengan lembaga pemerintahan. Dalam penyelenggaraan pendidikan, komite sekolah turut berkontribusi dalam memanfaatkan potensi yang ada, sehingga semua potensi itu dikembangkan secara maksimal sesuai kapabilitas masing-masing.

Berdasar uraian di atas dapat dipahami bahwa lingkungan sekolah bukanlah suatu badan yang berdiri sendiri, melainkan suatu bagian yang tidak terpisahkan dari masyarakat luas. Karena pendidikan merupakan tanggung jawab bersama antara sekolah, orang tua peserta didik, masyarakat dan pemerintah maka selayaknya semua unsur dan komponen tersebut melakukan kerjasama yang baik untuk memajukan kualitas pelayanan yang mengarah pada terbentuknya partisipasi masyarakat terhadap penyelenggaraan sekolah yang berkualitas.

Namun demikian, setelah kurang lebih 15 tahun berjalan, keberadaan komite sekolah di suatu lembaga pendidikan tidak selalu di fungsikan dengan baik atau tepat dalam melaksanakan peran dan fungsi sebagai mitra sekolah. Akibatnya komite sekolah hanya sebagai pelengkap struktural, komite sekolah juga hanya terlihat saat diadakannya acara-acara yang melibatkan anak muridnya, jadinya terkesan hanya sebagai tamu undangan yang menghadiri sebuah acara yang diadakan oleh pihak satuan pendidikan.

Laporan sekretaris komite SMA 1 Bone, Andi Kadir terhadap ketua komite Starifuddin Matjid ke Unit Sentra Pelayanan Kepolisian Terpadu (SPKT) Polres Bone. Laporan Andi Kadir ini terkait dugaan tindak pidana pungutan liar (pungli)

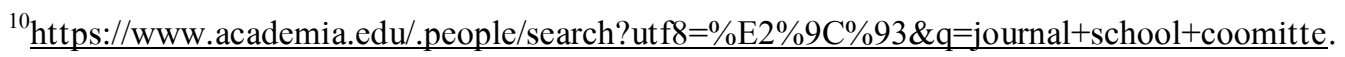
Diakses: Jumat, 5 Oktober 2018.
} 
yang dilakukan oleh ketua komite sekolah dalam hal ini Syarifuddin Madjid. Dalam laporannya, Andi Kadir menyatakan bahwa Syarifuddin Madjid sebagai ketua komite sekolah melakukan pungutan kepada orang tua siswa untuk membeli komputer sebagai sarana dalam pelaksanaan UNBK tanpa sepengetahuan atau kesepakatan rapat internal anggota komite ${ }^{11}$.

Dalam kasus yang lain ketua komite SMAN 2 Cenrana (SMAN 27 Bone) dilaporkan oleh salah seorang orang tua siswa yang berinisial SU dia membeberkan adanya pungutan melalui komite sekolah dengan pembayaran senilai Rp.50 ribu perbulan, dengan total Rp.500.000 pertahun dengan batas sampai pelaksanaan ujian kenaikan kelas. Parahnya pungutan yang berkedok sumbangan untuk pagar dan gerbang sekolah ini terkesan dipaksakan "Siswa tidak diikutkan ujian jika pembayaran ini tidak lunas" kalau dilihat acuan dari Permendikbud Nomor 76 Tahun 2016 tentang Komite Sekolah sudah jelas, bahwa selama tidak memberatkan siswa dan ada kesepakatan wajib dilakukan demi kelancaran pendidikan, selama itu tidak bersifat wajib, mengikat, serta jumlah dan jangka waktu pemungutannya ditentukan. ${ }^{12}$

Berdasarkan fenomena-fenomena yang terjadi di Kabupaten Bone menimbulkan pertanyaan apakah kebaradaan komite sekolah di satuan pendidikan masih di butuhkan atau tidak? Tulisan ini akan mengurai tentang peran komite sekolah sebagai pemberi pertimbangan (advisory agency) dalam implementasi manajemen berbasis sekolah di SMA Negeri 19 Bone.

\section{KAJIAN TEORETIK}

\section{A. Konsep Komite Sekolah}

\section{Pengertian Komite Sekolah}

Komite Sekolah yang berkedudukan di setiap satuan pendidikan merupakan badan mandiri yang tidak memiliki hubugan hirarkis dengan lembaga pemerintahan. Komite Sekolah dapat terdiri atas satuan pendidikan atau berupa satuan pendidikan dalam jenjang yang sama atau beberapa satuan pendidikan yang berbeda jenjang, tetapi pada lokasi yang berdekatan atau satuan pendidikan yang dikelola suatu penyelenggara pendidikan atau karena pertimbangan lain.

Secara lebih umum Hasbullah mengemukakan Komite Sekolah merupakan badan mandiri yang mewadahi peran serta masyarakat dalam rangka meningkatkan mutu pemerataan dan efisiensi pengelolaan pendidikan di satuan pendidikan, baik pada pendidikan prasekolah, jalur pendidikan sekolah maupun jalur pendidikan luar sekolah. Anggota-anggota Komite Sekolah terdiri atas kepala sekolah dan dewan guru, orang tua peserta didik, dan masyarakat. Komite Sekolah merupakan badan yang bersifat mandiri, tidak mempunyai hubungan yang hirarkis dengan sekolah dan lembaga pemerintah lainnya. Komite Sekolah harus dibentuk berdasarkan prakarsa masyarakat yang peduli pendidikan, bukan didasarkan pada arahan atau instruksi dari lembaga pemerintahan. ${ }^{13}$.

\footnotetext{
${ }^{11}$ Ardy dan Irham https://radarbone.fajar.co.id/sekretaris-polisikan-ketua-komite-sekolah-dibone/. Diakses: Senin, 12 Februari 2018.

${ }^{12}$ Redaksi, https://radarbone.fajar.co.id/astaga-pungutan-komite-bermunculan-di-bone/. Diakses: Senin, 16 Juli 2018.

${ }^{13}$ Hasbullah, Otonomi Pendidikan (Kebijakan Otonomi Daerah dan Implikasinya Terhadap Penyelenggaraan Pendidikan (Jakarta: Rajawali Grafindo Persada, 2006), h. 47.
} 
Pendapat di atas sejalan dengan Peraturan Pemerintah Republik Indonesia No. 17 Tahun 2010 yang menyebutkan Komite Sekolah adalah lembaga mandiri yang beranggotakan orang tua/wali peserta didik, komunitas sekolah, serta tokoh masyarakat yang peduli pendidikan.

Secara lebih terperinci tentang anggota Komite Sekolah dikemukakan oleh Budimansyah:

Anggota Komite Sekolah berasal dari unsur masyarakat berupa perwakilan orang tua/wali peserta didik berdasarkan jenjang kelas yang dipilih secara demokratis, tokoh masyarakat (Ketua RT/RW/RK, Kepala Dusun, Ulama, Budayawan, Pemuka Adat), anggota masyarakat yang mempunyai perhatian atau dijadikan figur dan mempunyai perhatian untuk meningkatkan mutu pendidikan, pejabat pemerintah setempat (Kepala Desa/Lurah, Kepolisian, Koramil, Depnaker, Kadin, dan instansi lain), dunia usaha/industri (pengusaha industri, jasa, asosiasi, dan lain-lain), pakar pendidikan yang mempunyai perhatian pada peningkatan mutu pendidikan, organisasi profesi tenaga pendidikan (PGRI, ISPI, dan lain-lain), perwakilan peserta didik bagi tingkat SLTP/SMU/SMK yang dipilih secara demokratis berdasarkan jenjang kelas, dan perwakilan forum alumni SD/SLTP/SMU/SMK yang telah dewasa dan mandiri. Sementara anggota Komite Sekolah yang berasal dari unsur dewan guru, yayasan/lembaga penyelenggara pendidikan, Badan Pertimbangan Desa sebanyak-banyaknya berjumlah tiga orang. Jumlah anggota Komite Sekolah sekurang-kurangnya 9 orang dan jumlahnya harus gasal. Syarat-syarat, hak, dan kewajiban, serta masa keanggotaan Komite Sekolah ditetapkan di dalam $\mathrm{AD} / \mathrm{ART}^{14}$.

Jika dicermati beberapa uraian di atas menunjukkan bahwa untuk melaksanakan urusan dalam bidang pendidikan, komponen masyarakat tidak boleh tidak harus diajak bicara, harus dilibatkan, mulai dari memberikan masukan dalam perencanaan sampai dengan pengawasan serta penilaian program pendidikan. Itulah sebabnya, dalam pelaksanaan pendidikan, Kementerian Pendidikan dan Kebudayaan, Dinas Pendidikan Provinsi serta Dinas Pendidikan Kabupaten/Kota harus melibatkan komponen masyarakat sebagai mitra kerjasama. Termasuk satuan pendidikan, kepala sekolah juga harus menjalin hubungan dan kerjasama dengan komponen masyarakat yang tergabung dalam Komite Sekolah.

Penegasan ini sejalan dengan pendapat yang dikemukakan oleh Masduki bahwa Komite Sekolah merupakan partner kerja dengan sekolah, yang secara bersama mendorong partisipasi warga sekolah dan masyarakat, serta memberi masukan kepada sekolah sesuai dengan aspirasi masyarakat yang telah berkembang ${ }^{15}$.

Komite Sekolah sebagai sebuah organisasi dapat berjalan apabila semua anggota pengurusnya memiliki visi atau tujuan yang sama. Menurut Haryadi, tujuan dibentuknya Komite Sekolah adalah mengembangkan konsep yang berorientasi kepada pengguna (client model), berbagi kewenangan (power sharing and advocacy

\footnotetext{
${ }^{14}$ Dasim Budimansyah, Indikator Kinerja Dewan Pendidikan dan Komite Sekolah. (Online: http://.WWW.dikdasmen.depdiknas sentral/dewandik dan komite.go.id) (DiaksesTanggal 22 Januari 2012), h. 8 .

${ }^{15}$ Masduki, Studi Peran Kepala Sekolah dan Komite Sekolah (Online: http://. WwW. mbeproject net/mbe59.html)(Diakses Tanggal 22 Januari 2012), h. 3.
} 
model), dan kemitraan (partnership model) yang difokuskan pada peningkatan mutu pelayanan pendidikan ${ }^{16}$.

Tujuan di atas mengandung arti bahwa Komite Sekolah dibentuk agar ada suatu organisasi masyarakat Sekolah yang mempunyai komitmen dan loyalitas serta peduli terhadap peningkatan kualitas sekolah. Keberadaan Komite Sekolah harus bertumpu pada landasan partisipasi masyarakat dalam meningkatkan kualitas pelayanan dan hasil pendidikan di sekolah.

Sejalan dengan uraian di atas, Hasbullah mengemukakan tujuan dibentuknya Komite Sekolah adalah:

(a) mewadahi dan menyalurkan aspirasi dan prakarsa masyarakat dalam melahirkan kebijakan operasional dan program pendidikan di satuan pendidikan; (b) meningkatkan tanggung jawab dan peran masyarakat dalam penyelenggaraan pendidikan; (c) menciptakan suasana dan kondisi transparan, akuntabel, dan demokratis dalam penyelenggaraan dan pelayanan pendidikan yang bermutu di satuan pendidikan. Pendapat ini menunjukkan tujuan Komite Sekolah dibentuk agar ada suatu organisasi masyarakat sekolah yang mempunyai komitmen dan loyalitas serta peduli terhadap peningkatan kualitas sekolah, dengan tujuan utamanya adalah meningkatkan mutu pembelajaran di satuan pendidikan, sehingga dihasilkan lulusan yang bermutu ditinjau dari aspek akademik dan non akademik ${ }^{17}$.

Kedua pendapat tersebut menunjukkan bahwa tujuan Komite Sekolah dilakukan untuk membangun hubungan kemitraan antara orang tua dan masyarakat serta sekolah dengan maksud: (1) Komite Sekolah mampu mengakses dan mengoptimalisasi berbagai sumber daya untuk pemenuhan kebutuhan dan penyelesaian rencana pendidikan; (2) terciptanya sinergi antar pemangku kepentingan (masyarakat, keluarga dan Komite Sekolah) untuk mengoptimalkan upaya-upaya peningkatan mutu pendidikan dan pendidikan untuk semua. Sebab dengan adanya Komite Sekolah dihasilkan sinergi dan integrasi berbagai upaya peningkatan mutu pendidikan di satuan pendidikan.

Dalam konteks pembangunan daerah pendidikan seharusnya mampu memberikan respon yang tepat terhadap bantuan pembangunan dan aspirasi masyarakat yang dilayaninya. Hal ini berarti bahwa perumusan kebijakan dan pembuatan keputusan pendidikan hendaknya memperhatikan aspirasi yang berkembang di daerah itu. Penyelenggaraan pendidikan di sekolah pihak-pihak yang berkepentingan dengan sekolah itu, seperti orang tua dan masyarakat setempat, sepatutnya memiliki akses terhadap perumusan kebijakan dan pembuatan keputusan untuk kepentingan memajukan sekolah.

Terkait dengan peranan Komite Sekolah, Hasbulah mengemukakan hal-hal sebagai berikut.

(a) mendorong tumbuhnya perhatian dan komitmen masyarakat terhadap penyelenggaraan pendidikan yang bermutu; (b) melakukan upaya kerjasama

\footnotetext{
${ }^{16}$ Yadi Haryadi, dkk., Pemberdayaan Komite Sekolah: Bahan Pelatihan untuk Fasilitator Inti Komite Sekolah Tingkat Provinsi dan Kabupaten/Kota pada Modul Penguatan Lembaga Komite Sekolah, (Jakarta: Direktorat Jenderal Manajemen Pendidikan Dasar dan Menengah Kegiatan Peningkatan Kegiatan dan Usaha Manajemen Pendidikan Depdiknas RI, 2010), h. 3.

${ }^{17}$ Hasbullah, Otonomi Pendidikan (Kebijakan Otonomi Daerah dan Implikasinya Terhadap Penyelenggaraan Pendidikan, h. 60.
} 
dengan masyarakat (perorangan/organisasi/dunia usaha/dunia industri) dan pemerintah berkenaan dengan penyelenggaraan pendidikan yang bermutu; (c) menampung dan menganalisis aspirasi, ide, tuntutan, dan berbagai kebutuhan pendidikan yang diajukan oleh masyarakat; (d) memberikan masukan, pertimbangan, dan rekomendasi kepada satuan pendidikan mengenai: (1) Kebijakan dan program pendidikan; (2) Rencana Anggaran Pendidikan dan Belanja Sekolah (RAPBS); (3) Kriteria kinerja satuan pendidikan; (4) Kriteria tenaga pendidikan; (5) Kriteria fasilitas pendidikan; (6) Hal-hal lain yang terkait dengan pendidikan seperti: mendorong orang tua dan masyarakat berpartisipasi dalam pendidikan guna mendukung peningkatan mutu dan pemerataan pendidikan, menggalang dana masyarakat dalam rangka pembiayaan penyelenggaraan pendidikan di satuan pendidikan, serta melakukan evaluasi dan pengawasan terhadap kebijakan, program, penyelenggaraan, dan keluaran pendidikan di satuan pendidikan . (a) mendorong tumbuhnya perhatian dan komitmen masyarakat terhadap penyelenggaraan pendidikan yang bermutu; (b) melakukan upaya kerjasama dengan masyarakat (perorangan/organisasi/dunia usaha/dunia industri) dan pemerintah berkenaan dengan penyelenggaraan pendidikan yang bermutu; (c) menampung dan menganalisis aspirasi, ide, tuntutan, dan berbagai kebutuhan pendidikan yang diajukan oleh masyarakat; (d) memberikan masukan, pertimbangan, dan rekomendasi kepada satuan pendidikan mengenai: (1) Kebijakan dan program pendidikan; (2) Rencana Anggaran Pendidikan dan Belanja Sekolah (RAPBS); (3) Kriteria kinerja satuan pendidikan; (4) Kriteria tenaga pendidikan; (5) Kriteria fasilitas pendidikan; (6) Hal-hal lain yang terkait dengan pendidikan seperti: mendorong orang tua dan masyarakat berpartisipasi dalam pendidikan guna mendukung peningkatan mutu dan pemerataan pendidikan, menggalang dana masyarakat dalam rangka pembiayaan penyelenggaraan pendidikan di satuan pendidikan, serta melakukan evaluasi dan pengawasan terhadap kebijakan, program, penyelenggaraan, dan keluaran pendidikan di satuan pendidikan ${ }^{18}$.

Jadi, jelaslah bahwa Komite Sekolah berperanan mendorong tumbuhnya perhatian dan komitmen masyarakat terhadap penyelenggaraan pendidikan, memberikan masukan, pertimbangan, dan rekomendasi kepada pemerintah dan satuan pendidikan mengenai kebijakan dan program pendidikan seperti: kriteria kinerja daerah dalam bidang pendidikan, tenaga pendidikan, fasilitas pendidikan, dan hal-hal lain yang terkait dengan pendidikan, serta berperan dalam mendorong orang tua dan masyarakat untuk berpartisipasi dengan menggalang dana masyarakat dalam rangka pembiayaan penyelenggaraan pendidikan di satuan pendidikan.

Peranan Komite Sekolah secara umum dapat dilihat dari kutipan sebagi berikut:

(1) pemberi pertimbangan (advisory agency) dalam penentuan dan pelaksanaan kebijakan pendidikan di tingkat satuan pendidikan; (2) pendukung (supporting agency) baik yang berwujud finansial, pemikiran, maupun tenaga dalam penyelenggaraan pendidikan di satuan pendidikan; (3) pengontro (controlling

${ }^{18}$ Hasbullah, Otonomi Pendidikan (Kebijakan Otonomi Daerah dan Implikasinya Terhadap Penyelenggaraan Pendidikan, h. 93. 
agency) dalam rangka transparansi dan akuntabilitas penyelenggaraan dan keluaran pendidikan di satuan pendidikan; (4) mediator antara pemerintah dengan masyarakat di satuan pendidikan ${ }^{19}$.

\section{Peranan Komite Sekolah Sebagai Pemberi Pertimbangan}

Salah satu peranan Komite Sekolah adalah memberikan pertimbangan kepada sekolah atau yayasan. Dengan kata lain, sekolah dan yayasan pendidikan harus meminta pertimbangan kepada Komite Sekolah dalam merumuskan kebijakan, program, dan kegiatan sekolah termasuk juga dalam merumuskan visi, misi, dan tujuan sekolah.

Sebagaimana dikemukakan oleh Pantjiastuti bahwa idealnya sekolah dan yayasan harus meminta pertimbangan kepada Komite Sekolah baik dalam merumuskan kebijakan, program, dan kegiatan sekolah maupun merumuskan visi, misi, dan tujuan sekolah. Menurutnya, visi, misi, dan tujuan sekolah yang bersifat given, seperti di sekolah swasta dengan ciri khas tertentu. Tetapi terdapat beberapa visi, misi, dan tujuan sekolah yang harus dirumuskan bersama dengan Komite Sekolah seperti program unggulan apa saja yang ingin diterapkan oleh sekolah ${ }^{20}$.

Pertimbangan yang diberikan oleh Komite Sekolah didasarkan atas kepercayaan, rasa hormat, dan komitmen untuk visi bersama sehingga Komite Sekolah harus ikut serta dalam mengembangkan visi bersama dan rencana-rencana kemajuan sekolah serta melaksanakan perbaikan secara berkelanjutan dalam program atau layanan sekolah bagi siswa dan orang tua.

Menurut Raynolds, sikap dan tanggungjawab Komite Sekolah dalam memberikan pertimbangan pada tahap awal kegiatan bersama dengan komunitas sekolah, yaitu membangun suatu visi masa depan bersama, sebab visi bersama merupakan kunci petunjuk untuk menerapkan peranan Komite Sekolah. Tujuan visi bersama adalah untuk menentukan arah keseluruhan kegiatan dan keputusan Komite Sekolah, memberikan satu bahasa yang umum untuk digunakan dalam diskusi tentang program pendidikan dan layanan sekolah sebagai gambaran ideal untuk masa depan dan menjadi dokumen kerja untuk saat sekarang ${ }^{21}$.

Komite Sekolah dalam hal ini bertanggungjawab dalam penyusunan perencanaan strategis dan tahunan khususnya dalam penyusunan RAPBS (Rancangan Anggaran Pendapatan dan Belanja Sekolah), pertimbangan dalam hal kebijakan dan program sekolah, dan memberikan pertimbangan dalam hal pelaksanaan program pendidikan serta penilaian pengelolaan sumber daya pendidikan berupa pertimbangan tentang potensi sumber daya pendidikan dalam masyarakat, tenaga kependidikan, sarana dan prasarana, serta anggaran. ${ }^{22}$

Penerapan peranan Komite Sekolah sebagai advisory agency (pemberi pertimbangan) ini termanifestasi dalam tiga aspek yaitu:

a. Perencanaan sekolah yang meliputi: (1) identifikasi sumber daya pendidikan dalam masyarakat, (2) memberikan masukan untuk penyusunan RAPBS, (3)

\footnotetext{
${ }^{19}$ Yadi Haryadi, dkk., Pemberdayaan Komite Sekolah, h. 17.

${ }^{20}$ Sri Renani Pantjastuti, dkk., Komite Sekolah, Sejarah dan Prospeknya di Masa Depan (Yogyakarta: Hikayat Publishing, 2008), h. 81-82.

${ }^{21}$ Larry J. Raynolds, Kiat Sukses Manajemen Berbasis Sekolah; Pedoman bagi Praktisi Pendidikan. terj. Teguh Budiharso (Cet.II; Jakarta: Diva Pustaka, 2005), h. 166.

${ }^{22}$ Tim Dosen Administrasi Pendidikan UPI, Manajemen Pendidikan (Cet. IV; Bandung: Alfabeta, 2011), h. 283.
} 
menyelenggarakan rapat RAPBS (sekolah, orang tua peserta didik, masyarakat), (4) memberikan pertimbangan perubahan RAPBS dan ikut mengesahkan RAPBS bersama Kepala Sekolah.

b. Pelaksanaan program kurikulum, proses pembelajaran dan penilaian yang mencakup: (1) memberikan masukan terhadap proses pengelolaan pendidikan di sekolah dan (2) memberikan masukan terhadap proses pembelajaran kepada para guru.

c. Penilaian pengelolaan sumber daya pendidikan yang mencakup: (1) identifikasi potensi sumber daya pendidikan dalam masyarakat, (2) memberikan pertimbangan tentang tenaga kependidikan yang dapat diperbantukan di sekolah, (3) memberikan pertimbangan tentang sarana dan prasarana yang dapat diperbantukan di sekolah dan (4) memberikan pertimbangan tentang anggaran yang dapat dimanfaatkan di sekolah. ${ }^{23}$

Uraian di atas mengisyaratkan bahwa Komite Sekolah sebagai partner kerja sekolah, dalam aplikasinya turut membantu memberi pertimbangan, kebijakan, menyalurkan ide, dan berbagai kebutuhan pendidikan serta menampung dan menganalisa aspirasi dan memberi rekomendasi kepada sekolah dalam rangka meningkatkan mutu pendidikan.

Penentuan dan pelaksanaan kebijakan pendidikan di tingkat satuan pendidikan, minimal dalam memberikan masukan, pertimbangan, dan rekomendasi kepada satuan pendidikan. Supaya masukan tersebut sesuai dengan kebutuhan satuan pendidikan, diperlukan informasi-informasi yang didasarkan pada kegiatan-kegiatan sebagai berikut:

(1) Mengadakan pendataan kondisi sosial ekonomi masyarakat dan sumber daya pendidikan di masyarakat sekitar sekolah. (2) Menganalisis hasil pendataan sebagai bahan pemberian masukan pertimbangan dan rekomendasi kepada sekolah. (3) Menyampaikan masukan, pertimbangan atau rekomendasi secara tertulis kepada sekolah. (4) Memberikan pertimbangan kepada sekolah dalam rangka pengembangan Kurikulum Tingkat Satuan Pendidikan (KTSP). (5) Memberikan pertimbangan kepada sekolah untuk meningkatan mutu pembelajaran. (6) Memberikan pertimbangan kepada sekolah untuk menyelenggarakan pembelajaran yang menyenangkan (PAKEM). (7) Memberikan masukan dan pertimbangan kepada sekolah dalam penyusunan visi, misi, tujuan, kebijakan, program dan kegiatan pendidikan di sekolah. (8) Memberikan masukan dan pertimbangan kepada sekolah dalam penyusunan RAPBS. ${ }^{24}$

Secara singkat Indra Jati Sidi mengemukakan pendapatnya bahwa Komite Sekolah dapat memberikan pertimbangan berupa masukan penilaian untuk pengembangan pelaksanaan pendidikan, baik intrakurikuler maupun ekstrakurikuler, dan pelaksanaan manajemen sekolah yang meliputi kepala sekolah, guru, peserta

\footnotetext{
${ }^{23}$ Keputusan Menteri Pendidikan Nasional Republik Indonesia Nomor 044/U/2002. Yadi Haryadi, dkk., Pemberdayaan Komite Sekolah, h. 15.

${ }^{24}$ Deparetemen Pendidikan Nasional RI, Panduan Umum Dewan Pendidikan dan Komite Sekolah (Jakarta: Direktorat Pendidikan Dasar dan Menengah, 2002), h. 26.
} 
didik, dan karyawan. Selain itu, Komite Sekolah dapat memberikan pertimbangan bagi pembahasan atas usulan RAPBS. ${ }^{25}$

Mengacu pada peranan di atas, menunjukkan bahwa Komite Sekolah sebagai badan penasehat, penting untuk memberikan pertimbangan dalam pelaksanaan proses pendidikan di sekolah, termasuk pelaksanaan program kurikulum, proses pembelajaran, dan penilaian. Hal ini penting, mengingat diberlakukannya otonomi pendidikan dengan pengelolaan pendidikan yang lebih otonom di sekolah, guru memiliki peranan penting dalam penciptaan proses pembelajaran yang kondusif bagi sarana demokratisasi pendidikan.

\section{B. Konsep Manajemen Berbasis Sekolah}

\section{Pengertian Manajemen Berbasis Sekolah}

Manajemen Berbasis Sekolah merupakan bagian dari manajemen pendidikan. Oleh karena itu, sebelum membahas tentang pengertian MBS akan dibahas terlebih dahulu pengertian manajemen pendidikan. Arikunto dan Yuliana mengemukakan bahwa manajemen pendidikan adalah suatu kegiatan atau rangkaian kegiatan yang berupa proses pengelolaan usaha kerjasama sekelompok manusia yang tergabung dalam organisasi pendidikan, untuk mencapai tujuan pendidikan yang telah ditetapkan sebelumnya agar efektif dan efisien. ${ }^{26}$ Sementara itu, Made Pidarta mengartikan manajemen pendidikan sebagai aktivitas memadukan sumber-sumber pendidikan agar terpusat dalam usaha mencapai tujuan pendidikan yang telah ditentukan sebelumnya ${ }^{27}$.

Pendapat yang lain menurut Tilaar dalam Sulistyorini dan Fathurrahman mendefinisikan manajemen pendidikan adalah proses pengelolaan lembaga pendidikan dengan mobilisasi sumber-sumber pendidikan dan segala hal yang terkait untuk mencapai tujuan yang telah ditetapkan secara efektif dan efisien. ${ }^{28}$

Sedangkan manajemen pendidikan Islam menurut Mujamil Qomar adalah suatu proses pengelolaan secara Islami terhadap lembaga pendidikan Islam dengan cara menyiasati sumber-sumber belajar dan hal-hal yang terkait untuk mencapai tujuan pendidikan Islam secara efektif dan efisien. ${ }^{29}$ Berbeda dengan Ramayulis, menurutnya manajemen pendidikan Islam sebagai proses pemanfaatan semua sumber daya yang dimiliki, baik perangkat keras maupun lunak. Pemanfaat tersebut melalui kerjasama dengan orang lain secara efektif, efisien, dan produktif untuk mencapai kebahagian dan kesejahteraan, baik di dunia maupun di akhirat. ${ }^{30}$

Menurut Sulastryorini manajemen pendidikan Islam dapat dirumuskan sebagai berikut: suatu proses penataan atau pengelolaan secara Islami terhadap lembaga

\footnotetext{
${ }^{25}$ Indra Jati Sidi, Menuju Masyarakat Belajar: Menggagas Paradigma Baru Pendidikan. (Cet. I; Jakarta: Logos Wacana Ilmu, 2001), h. 135.

${ }^{26}$ Suharsimi Arikunto dan Lia Yuliana, Manajemen Pendidikan (Yogyakarta: Aditya Media, 2008), h. 4.

${ }^{27}$ Made Pidarta, Manajemen Pendidikan Indonesia, (Jakarta: PT Bina Aksara, 2011), h. 8.

${ }^{28}$ Sulistyorini dan Muhammad Fathurrohman, Esensi Manajemen Pendidikan Islam: Pengelolaan Lembaga untuk Meningkatkan Kualitas Pendidikan Islam (Yogyakarta: Teras, 2014), h. 11.

${ }^{29}$ Mujamil Qomar, Manajemn Pendidikan Islam: Strategi Baru Pengelolaan Lembaga Pendidikan Islam (Jakarta: Erlangga, 2008), h. 6.

${ }^{30}$ Ramayulis, Ilmu Pendidikan Islam (Jakarta: Kalam Mulia, 2010), h. 261.
} 
pendidikan Islam yang melibatkan sumber daya manusia Muslim dalam menggerakkan untuk mencapai tujuan pendidikan Islam secara efektif dan efisien. ${ }^{31}$

Rohiat mendefinisikan bahwa manajemen sekolah adalah melakukan pengelolaan sumber daya yang dimiliki sekolah/organisasi. Adapun sumber daya yang dimiliki sekolah adalah: manusia, uang, metode, material, mesin, dan pemasaran, pengelolaan dilakukan secara sistematis dalam suatu proses yang berlangsung dalam dunia pendidikan. Tujuan dari pengelolaan sekolah adalah mendayagunakan sumber daya yang dimiliki secara terintegrasi dan terkoordinasi untuk mencapai tujuan sekolah. ${ }^{32}$

Manajemen pendidikan di sini dimaksudkan sebagai rangkaian kegiatan yang berupa proses pengelolaan sumber daya sekolah yang meliputi perencanaan, pengorganisasian, pelaksanaan dan pengawasan terhadap komponen sekolah. Hal itu dilakukan dalam rangka pencapaian tujuan peningkatan mutu sekolah sebagai upaya peningkatan mutu pendidikan. Pencapaian tujuan peningkatan mutu sekolah sangat ditentukan oleh visi, misi, dan tujuan sekolah yang telah ditetapkan sebelumnya

Pada hakikatnya istilah manajemen pendidikan dan manajemen sekolah mempunyai makna dan maksud yang sama. Keduanya sulit untuk dibedakan, karena kedua istilah tersebut sering dipakai secara bergantian dalam pengertian yang sama. Apa yang menjadi bidang manajemen pendidikan adalah juga merupakan bidang manajemen sekolah. Demikian pula proses kerjanya ditempuh melalui fungsi-fungsi yang sama, yang diturunkan dari teori administrasi dan manajemen pada umumnya.

Dilihat dari asal usul peristilahan, Manajemen Berbasis Sekolah (MBS) merupakan terjemahan langsung dari School-Based Management (SBM). Sedangkan secara leksikal, Nurkolis menyatakan Manajemen Berbasis Sekolah berasal dari tiga kata, yaitu manajemen, berbasis, dan sekolah. Manajemen merupakan proses menggunakan sumber daya secara efektif untuk mencapai sasaran. Berbasis memiliki kata dasar basis yang berarti dasar atau asas. Sekolah merupakan lembaga untuk belajar dan mengajar serta tempat menerima dan memberikan pelajaran. Berdasarkan makna leksikal tersebut maka MBS dapat diartikan sebagai penggunaan sumber daya yang berasaskan pada sekolah itu sendiri dalam proses pengajaran atau pembelajaran. ${ }^{33}$

Myers dan Stonehill dalam Nurkolis mengartikan MBS adalah strategi untuk memperbaiki mutu pendidikan dengan mentransfer otoritas pengambilan keputusan secara signifikan dari pemerintah pusat dan daerah ke sekolah-sekolah secara individual. $^{34}$

Menurut E. Mulyasa: "MBS merupakan salah satu wujud dari reformasi pendidikan yang menawarkan kepada sekolah untuk menyediakan pendidikan yang lebih baik dan memadai bagi peserta didik. Otonomi dalam manajemen merupakan potensi bagi sekolah untuk meningkatkan kinerja para staf, menawarkan partisipasi

${ }^{31}$ Sulistyorini, Manajemen Pendidikan Islam: Konsep, Strategi Dan Aplikasi (Yogyakarta: Teras, 2009), h. 13.

${ }^{32}$ Rohiat, Manajemen Sekolah: Teori dasar dan Praktek (Bandung: Refika Aditama, 2008), h. 14.

${ }^{33}$ Nurkolis, Manajemen Berbasis Sekolah: Teori, Model, dan Aplikasi (Jakarta: PT Grasindo, 2005), h. 1.

${ }^{34}$ Nurkolis, Manajemen Berbasis Sekolah: Teori, Model, dan Aplikasi, h. 3. 
langsung kelompok-kelompok yang terkait, dan meningkatkan pemahaman masyarakat terhadap pendidikan. ${ }^{35}$

Mulyono dengan mengutip pendapat Eman Suparman mengatakan, MBS dapat didefinisikan dalam penyerasian sumber daya yang dilakukan secara mandiri oleh sekolah dengan melibatkan semua kelompok kepentingan yang terkait dengan sekolah secara langsung dalam proses pengambilan keputusan untuk memenuhi kebutuhan mutu sekolah atau untuk mencapai tujuan mutu sekolah dalam pendidikan nasional. $^{36}$

Selain itu, Nurkolis mengatakan MBS dengan Manajemen Peningkatan Mutu Berbasis Sekolah (MPMBS). MPMBS diartikan sebagai model manajemen yang memberi otonomi lebih besar pada sekolah dan mendorong pengambilan keputusan partisipatif yang melibatkan secara langsung semua warga sekolah untuk meningkatkan mutu sekolah berdasarkan kebijakan pendidikan nasional. ${ }^{37}$

Adapun Bappenas dan Bank Dunia, seperti yang dikutip oleh B. Suryosubroto, memberikan pengertian manajemen berbasis sekolah adalah pemberdayaan sekolah dengan memberikan otonomi yang lebih besar di samping menunjukkan sikap tanggap pemerintah terhadap tuntutan masyarakat juga dapat ditunjukkan sebagai sarana peningkatan efisiensi, mutu, dan pemerataan pendidikan. ${ }^{38}$

Sesungguhnya istilah MBS, atau Manajemen Berbasis Sekolah merupakan terjemahan dari school based management, istilah ini pertama kali muncul di Amerika Serikat ketika masyarakat mulai mempertanyakan relevansi pendidikan dengan tuntutan dan perkembangan masyarakat setempat. ${ }^{39}$

Menurut Syaiful Sagala bahwa kekuasaan yang dimiliki sekolah mancakup antara lain:

(a) mengambil keputusan berkaitan dengan kurikulum. (b) keputusan berkaitan dengan rekrutmen dan pengelolaan guru serta pegawai administrasi. (c) keputusan berkaitan dengan pengelolaan sekolah. ${ }^{40}$

Dari sekian banyak nama atau istilah terkait MBS dapatlah dikatakan bahwa MBS adalah suatu proses kerja komunitas sekolah dengan cara menerapkan kaidahkaidah otonomi, akuntabilitas, partisipasi dan transparansi untuk mencapai tujuan pendidikan dan pembelajaran secara bermutu, sehingga secara sederhana dapat dikatakan bahwa MBS adalah proses desentralisasi kewenangan pembuatan keputusan pada tingkat sekolah.

\section{Karakteristik Manajemen Berbasis Sekolah}

Manajemen berbasis sekolah memiliki karakteristik yang perlu dipahami oleh sekolah yang menerapkanya. Dengan kata lain jika sekolah ingin sukses dalam menerapkan manajemen berbasis sekolah maka sejumlah karakteristik MBS berikut perlu dimiliki. Karakteristik MBS tidak dapat dipisahkan dengan karakteristik sekolah

\footnotetext{
${ }^{35}$ E. Mulyasa, Menjadi Kepala Sekolah Profesional. Dalam Konteks Menyukseskan MBS dan KBK,E. (Bandung: PT remaja Rosdakarya, 2007), h. 24.

${ }^{36}$ Mulyono, Manajemen Administrasi dan Organisasi Pendidikan (Jogjakarta: Ar-Ruzz Media, 2010), h. 239.

${ }^{37}$ Nurkolis, Manajemen Berbasis Sekolah: Teori, Model, dan Aplikasi, h. 9.

${ }^{38}$ B. Suryosubroto, Manajemen Pendidikan di Sekolah (Jakarta: PT Rineka Cipta, 2004), h. 195.

${ }^{39}$ Ibtisam Abu Duhou, School Based Management, (Jakarta: Kencana, 2004), h. 24.

${ }^{40}$ Syaiful Sagala, Administrasi Pendidikan Kontemporer (Bandung: CV Alfabeta, 2008), h. 80.
} 
yang efektif (effective schoo). Jika MBS merupakan sebuah wadah atau kerangkanya maka sekolah efektif merupakan isinya. Oleh karena itu karakteristik MBS memuat secara inklusif elemen-elemen sekolah yang efektif, yang dikategorikan menjadi input, proses, dan output.

Sedangkan karakteristik MBS dilihat dari aspek input pendidikan adalah memilki kebijakan, tujuan dan sasaran mutu yang jelas dan sumber daya yang tersedia, staf yang berkompeten dan berdedikasi yang tinggi, dan memiliki harapan prestasi yang tinggi, fokus pada pelanggan (khususnya siswa) serta input manajemen. ${ }^{41}$

Sekolah yang efektif pada umumnya memiliki karakterisik proses yaitu; proses pembelajaran yang efektifitasnya tinggi, kepemimpinan sekolah yang kuat, lingkungan sekolah yang aman dan tertib, pengelolaan tenaga kependidikan yang efektif, sekolah memiliki budaya mutu, sekolah memiliki tiemwork yang kompak, cerdas dan dinamis, sekolah memiliki kemandirian, partisipasi yang tinggi dari warga sekolah dan masyarakat, transparansi manajemen, sekolah memilki kemauan yang berubah, sekolah melakukan evaluasi dan perbaikan secara berkelanjutan, sekolah responsif dan antisipatif terhadap kebutuhan dan memiliki akuntabilitas. mencakup:

Karakteristik utama dan efektif dalam penerapan MBS di sekolah

a. Otonomi Sekolah

Otonomi diartikan sebagai kewenangan atau kemandirian, yaitu kemandirian dalam mengatur dan mengurus dirinyan sendiri dan tidak tergantung dengan orang lain. Kemandirian dalam program pendanaan merupakan tolak ukur utama kemandirian sekolah. Pada gilirannya, kemandirian yang berlangsung secara terus menerus akan menjamin kelangsungan hidup dan perkembangan sekolah.

b. Fleksibilitas

Fleksibilitas dapat diartikan sebagai keluwesan yang diberikan kepada sekolah untuk mengelola, memanfaatkan dan memberdayakan sumber daya sekolah seoptimal mungkin untuk meningkatkan sekolah. Dengan keluwesan yang lebih besar yang diberikan kepada sekolah, sekolah akan lebih lincah dan tidak harus menunggu arahan dari atasannya dalam mengelola, memanfaatkan dan memberdayakan sumber dayanya. Dengan cara ini, sekolah akan lebih responsif dan lebih cepat dalam menanggapi segala tantangan yang dihadapi. Namun demikiaan, keluwesan yang dimaksud harus tetap dalam koridor kebijakan dan peraturan perundang-undangan yang ada.

c. Kerjasama

MBS yang mampu meningkatkan kualitas pendidikan menuntut adanya kerjasama antara staf yang ada dalam sekolah. Dampaknya akan menguntungkan anak didik, khususnya pentingnya team work dalam proses pembelajaran.

d. Partisipatif

Peningkatan partisipatif yang dimaksudkan adalah menciptakan lingkungan yang terbuka dan demokratis. Warga sekolah (guru, siswa, karyawan, dan masyarakat) didorong untuk terlibat secara langsung dalam penyelenggaraan pendidikaan mulai dari pengambilan keputusan, pelaksanaan, dan evaluasi pendidikan yang diharapkan dapat meningkatkan mutu pendidikan. ${ }^{42}$

\footnotetext{
${ }^{41}$ Hasbullah, Dasar-dasar Ilmu Pendidikan (Cet. II; Jakarta: Raja Grafindo Persada, 2001), h. 56.

${ }^{42}$ Rohiat, Manajemen Sekolah, Teori Dasar dan Praktik ( Cet. II; Bandung: Refika Aditama, 2009), h. 75-79
} 
Sementara itu, menurut Nurkholis yang dikutip Muhammad Syaifuddin dkk, MBS memiliki 8 karakter yaitu:

1. Sekolah memilki misi atau cita-cita menjalankan sekolah mewakili sekolompok harapan bersama, keyakinan dan nilai-nilai sekolah, membimbing warga sekolah di dalama aktivitas pendidikan dan member arah kerja. Misi mempunyai pengaruh yang besar terhadap fungsi dan efektifitas sekolah, karena dengan misi ini warga sekolah dapat mengembangkan budaya organisasi sekolah yang tepat, membangun komitmen yang tinggi terhadap warga sekolah, dan mempunyai inisiatif untuk memberikan tingkat layanan pendidikan yang lebih baik.

2. Aktivitas pendidikan dijalankan berdasarkan karakteristik kebutuhan dan situasi sekolah. Hakikat aktivitas sangat penting bagi sekolah untuk meningkatkan kualitas pendidikan, karena secara tidak langsung memperkenalkan perubahan manajemen sekolah dari manajemen kontrol eksternal menjadi manajemen berbasis sekolah.

3. Terjadinya proses perubahan strategi manajemen yang menyangkut hakikat manusia, organisasi sekolah, gaya pengambilan keputusan, gaya kepemimpinan, penggunaan kekuasaan, dan keterampilan-keterampilan manajemen. Oleh karena itu dalam konteks pelaksanaan manajemen berbasis sekolah perubahan strategi manajemen lebih memandang pada aspek pengembagan yang tepat dan relevan dengan kebutuhan sekolah.

4. Keleluasaan dan kewenangan dalam pengelolaan sumber daya yang efektif untuk mencapai tujuan pendidikan untuk memecahkan masalah-masalah pendidikan yang dihadapi, baik tenaga kependidikan, keuangan dan sebagainya.

5. Menuntut peran aktif sekolah, administrator sekolah, guru, orang tua, dan pihak-pihak yang terkait dengan pendidikan disekolah.

6. Menekankan hubungan yang cenderung terbuka, bekerja sama, semangat tim, dan komitmen yang saling menguntungkan.

7. Peran administrator sangat penting dalam kerangka MBS, termasuk di dalamnya kualitas yang dimiliki administrator.

8. Efektivitas sekolah dinilai menurut indikator multitingkat dan multi segi. Penilaian terhadap efektivitas sekolah harus mencakup proses pembelajaran dan metode untuk kemajuan sekolah. Oleh karena itu penilaian efektivitas sekolah harus memperhatikan multi tingkat, yaitu pada tingakt sekolah, kelompok dan individu, yaitu indikator multi segi yaitu input, proses dan output sekolah serta perkembangan akademik siswa. ${ }^{43}$

Selain dari karakteristik manajemen berbasis sekolah, ada beberapa faktor yang perlu diperhatikan sehubungan dengan manajemen berbasis sekolah yang berkaitan dengan (1) kewajiban sekolah, (2) kebijakan dan prioritas pemerintah, (3) peranan orang tua dan masyarakat, (4) peranan profesionalisme dan manajerial serta pengembangan profesi.

a) Kewajiban Sekolah

Manajemen berbasis sekolah yang menawarkan keleluasaan pengelolalaan sekolah memiliki potensi yang besar dalam menciptakan kepala sekolah, guru, dang pengelolah sekolah professional. Oleh karena itu pelaksanaan perlu disertai

\footnotetext{
${ }^{43}$ Lihat Muhammad Syaifuddin dkk, Manajemen Sekolah (Depdiknas, 2007), h. 19-20
} 
seperangkat kewajiban, serta monitoring dan tuntutan pertanggungjawaban (akuntabel) yang relatif tinggi, untuk menjamin bahwa sekolah selain memiliki otonomi juga mempunyai kewajiban melaksanakn kebijakan pemerintah dan memenuhi harapan masyarakat sekolah. Dengan demikian, sekolah ditunt menampilkan pengelolaan sumber daya secara transparan, demokratis, tanpa monopoli, dan bertanggung jawab baik terhadap masyarakat maupun pemerintah, dalam rangka meningktakan kapasitas pelayanan terhadap peserta didik.

b) Kebijakan dan Prioritas Pemerintah

Pemerintah sebagai penanggung jawab pendidikan nasional berhak merumuskan kebijakan-kebijakan yang menjadi prioritas nasional terutama yang berkaitan dengan program peningkatan melek huruf dan angka (literacy and numeracy), efisiensi, mutu, dan pemerataan pendidikan. Dalam hal-hal tersebut, sekolah tidak diperbolehkan untuk berjalan sendiri dengan mengabaikan kebijakan dan standar yang ditetapkan oleh pemerintah yang dipilih secara demokratis.

Agar prioritas-prioritas pemerintah dilaksanakan oleh sekolah dan semua aktifitas sekolah ditujukan umtuk memberikan pelayanan kepada peserta didik sehingga dapat belajar dengan baik, pemerintah perlu merumuskan seperangkat pedoman umum tentang pelaksanaan MBS. Pedoman-pedoman tersebut, terutama, ditunujakn untuk menjamin bahwa hasil pendidikan (student outcomse) terevaluasi dengan baik, kebijakan-kebijakan pemerintah dilaksanakan secara efektif, sekolah dioperasikan dalam kerangka yang disetujui pemerintah, dan anggaran dibelanjakan sesuai dengan tujuan.

c) Peranan Orang Tua dan Masyarakat

MBS menuntut dukungan kerja yang terampil dan berkualitas untuk membangkitkan motivasi kerja yang lebih produktif dan meberdayakan otoritas daerah setempat, serta mengefesienkan system dan mengilangkan birokrasi yang tumpah tindih. Untuk kepentingan tersebut, diperlukan partisipasi masyarakat, dan hal ini merupakan salah satu aspek penting dalam manajemen berbasis sekolah. Melalui dewan sekolah (school council), orang tua dan masyarakat dapat berbartisipasi dalam pembuatan berbagai keputusan. Dengan demikian, masyarakat dapat lebih memahami, serta mengawasi dan membantu sekolah dalam pengelolaan termasuk kegiatan belajar mengajar. Besarnya partisipasi masyarakat dalam pengelolaan sekolah tersebut, mengkin dapat menimbulkan rancunya kepentingan antara sekolah, orang tua, dan masyarakat. Dalam hal ini pemerintah perlu merumuskan bentuk partisipasi (pembagian tugas) setiap unsur secara jelas dan tegas.

d) Peranan Profesionalisme dan Manajerial

Manajemn berbasis sekolah menutut perubahan-perubahan tingkah laku kepala sekolah, guru, dan tenaga administrasi dalam mengoprasikan sekola. Pelaksanaan MBS berpotensi meningkatkan gesekan peranan yang bersifat professional dan manajerial. Untuk memenuhi persyaratan pelaksanaan MBS, kepala sekolah, guru, dan tenaga administrasi harus memiki kedua sifat tersebut, yaitu professional dan manajerial. Mereka harus memiliki pengetahuan yang dalam tentang peserta didik dan prinsipprinsip pendidikan untuk menjamin bahwa segala keputusan penting yang dibuat oleh sekolah, didasarkan atas pertimbangan-pertimbangan pendidikan. Kepala sekolah khususnya, perlu mempelajari dengan teliti, baik kebijakan dan prioritas pemerintah maupun prioritas sekolah sendiri. Untuk kepentingan tersebut, kepala sekolah harus: 
1) Memilik kemampuan untuk berkolaborasi dengan guru dan masyarakat sekitar sekolah;

2) Memiliki pemahaman dan wawasan yang luas tentang teori pendidikan dan pembelajaran;

3) Memiliki kemampuan dan keterampilan untuk menganalisis situasi sekarang berdasarkan apa yang seharusnya serta mampu memperkirakan kejadian masa depan berdasarkan situasi sekarang;

4) Memiliki kemauan dan kemampuan untuk mengedintifaksi masalah dan kebutuhan yang berkaitan dengan efektifitas pendidikan di sekolah; dan

5) Mampu memanfaatkan berbagai peluang, menjadikan tantangan sebagai peluang, serta mengkonseptualkan arah baru untuk perubahan.

Pemahaman terhadap sifat professional dan manajerial tersebut sangat penting agar peningkatan efesiensi, mutu, dan pemerataan serta supervisi serta monitoring yang direncanakan sekolah betul-betul untuk mencapai tujuan pendidikan sesuai dengan kerangka kebijakan pemerintah dan tujuan sekolah.

\section{e) Pengembangan Profesi}

Dalam MBS pemerintah harus menjamin bahwa semua unsur penting tenaga kependidikan (sumber manusia) menerima pengenbangan profesi yang diperlukan untuk mengelolah sekolah secara efektif. Agar sekolah dapat mengambil manfaat yang ditawarkan MBS, perlu dikembangkan adanya pusat pengembangan profesi, yang berfungsi sebagai penyedia jasa pelatihan bagi tenaga kependidikan untuk MBS. Selain itu, penting untuk dicatat bahwa sebaiknya sekolah dan masyarakat perlu dilibatkan dalam proses pelaksanaan MBS sedini mungkin. Mereka tidak perlu hanya menunggu, tetapi melibatkan diri dalam diskusi-diskusi tentang MBS dan berinisiatif untuk menyelenggarakan pelatiahan tentang aspek-aspek yang terkait. ${ }^{44}$

Dengan demikian dapat dipahami bahwa penerapan manajemen berbasis sekolah bisa diketahui sejauh mana sekolah dapat mengoptimalkan organisasi sekolah, proses pembelajaran, pengelolaan sumber daya manusia, dan pengelolaan sumber daya dan administrasi.

\section{METODOLOGI PENELITIAN}

Jenis penelitian ini adalah kualitatif yang dilaksanakan di SMA Negeri 19 Bone, yang terletak di Desa Masago Kecamatan Patimpeng Kabupaten Bone Provinsi Sulawesi Selatan. Pendekatan yang digunakan adalah pendekatan pedagogik, sosiologis, dan manajerial. Sumber data primer dalam penelitian ini adalah kepala sekolah, ketua komite, guru dan tenaga kependidikan sekolah, orang tua siswa dan masyarakat. Sedangkan data sekunder berupa dokumentasi penting menyangkut profil sekolah dan dokumen-dokumen yang berkaitan dengan penelitian. Pengumpulan data dilakukan dengan pengamatan, wawancara, cacatan lapangan, dan studi dokumentasi. Instrument yang digunakan oleh peneliti yaitu panduan observasi, pedoman wawancara, dan format catatan dokumentasi. Data diolah dan dianalisis dengan reduksi data, penyajian data, penarikan kesimpulan atau verifikasi. Keabsahan data diuji dengan triangulasi dan konfirmabilitas.

\footnotetext{
${ }^{44}$ E. Mulyasa, Manajemen Berbasis Sekolah Konsep Strategi dan Implementasi (Bandung: Rosdakarya, 2011), h. 27-29
} 


\section{HASIL PENELITIAN DAN PEMBAHASAN}

Komite sekolah mempunyai tugas memberikan pertimbangan dan masukan serta saran dalam kegiatan pembelajaran maupun kegiatan ekstrakulikuler serta dalam hal sarana dan prasarana sekolah. Jelas hal ini akan membantu dan menjaga kelancaran kegiatan sekolah yang dilaksanakan. Keberadaan masukan dalam bentuk nyata perlu kiranya dikelola dengan baik. Karena komite sekolah sebagai jembatan sekolah antara orang tua dan guru akan terasa manfaatnya jika ini digali dengan sangat serius terutama untuk mendukung kelancaran dalam melaksanakan program pembalajaran di sekolah.

Komite sekolah sebagai pemberi pertimbangan dalam penentuan dan pelaksanaan program pendidikan di satuan pendidikan, dengan indikator peran sebagai pemberi pertimbangan terhadap 1) kebijakan program pendidikan dan Rancangan Anggaran Pendapatan dan Belanja Sekolah (RAPBS), 2) Kriteria Kinerja tenaga pendidikan, dan 3) Kriteria fasilitas atau sarana prasarana pendidikan.

Berdasarkan indikator peran komite yang dikemukakan di atas, selanjutnya akan dijabarkan ke dalam indikator pelaksanaan peran komite sekolah di SMA Negeri 19 Bone sebagai berikut:

\section{1) Kebijakan program pendidikan dan RAPBS}

Pelaksanaan peran komite sekolah membutuhkan sebuah perumusan kebijakan yang dapat menjadi acuan bagi komite sekolah dalam mengimplemtasikan berbagai program yang ada demikian halnya dengan kebijakan program pendidikan dan RAPBS. Kebijakan demikian ini pada gilirannya akan dapat mempengaruhi bagaimana peran itu akan mewujudkan kelak dikemudian hari. Bentuk tujuan-tujuan kebijakan juga membawa dampak terhadap implementasinya. Dalam hal ini apakah tujuan-tujuan itu telah dirumuskan dengan jelas ataukah masih kabur, dan apakah sekolah dengan komite sekolah memiliki komitmen yang tinggi terhadap tujuan akhir dari sekolah bagaimana agar kehadiran komite sekolah ikut andil dalam menyukseskan program pendidikan dan selayaknya kebijakan yang dibentuk sekolah akan mendukung kegiatan-kegiatan komite, wawan cara dengan ketua komite mengatakan bahwa:

Komite sekolah secara pasti ikut menyusun dan memberikan pertimbangan mengenai RAPBS karena banyak hal yang tidak selamanya didanai oleh dana BOS jadi dari situ kita lihat peran serta orang tua siswa tentang pendanaan yang tidak ada biayanya dari dana BOS tapi itu sangat-sangat membutuhkan dana termasuk penggajian guru honor, karena guru honor sekarang terbagi dua ada yag sifatnya honorir yang sudah mendapatkan gaji langsung dari pemerintah dan sekarang yang statusnya sukarela siapa yang mau gaji mereka siapa yang kasi uang bensin dan pembeli sabun kalau bukan kita dari komite. ${ }^{45}$

Hasil wawancara di atas dapat disimpulkan bahwa komite sekolah secara pasti turut memberikan langsung pertimbangan mengenai RAPBS karena ada pendanaanpendanaan yang tidak didanai oleh dana BOS seperti yang disebutkan di atas bahwa yang menggaji yang berstat us sukarela itu adalah komite sekolah, karena sukarela tidak mendapatkan gaji dari dana BOS.

Selanjutnya untuk melihat keabsahan data maka dilakukan wawancara kepada kepala sekolah sebagai trianggulator yang mengatakan bahwa:

Komite sekolah selalu kita libatkan di dalam penyusunan dan pengesahan

RAPBS karena komite sekolah ikut bertanda tangan dipengesahan, apabila ada

\footnotetext{
${ }^{45}$ Drs. H. Andi Zainal Abidin S.Pd., M.Si., M.kes, Ketua Komite, Wawancara, di Bajoe.
} 


\section{Peran Komite Sekolah Sebagai Advisory Agency dalam Implementasi Manajemen Berbasis Sekolah...}

pendanaan-pendanaan yang diluar dari pada dana yang ada misalnya penggajian yang berstatus sukarela itu kita carikan dana melalui komite sekolah karena mereka tidak masuk dalam tanggungan dana BOS. ${ }^{46}$

Berdasarkan hasil wawancara menggambarkan bahwa kehadiran komite sekolah pada sekolah SMA Negeri 19 Bone memberikan kontribusi positif dalam penyusunan RAPBS apalagi yang berkaitan dengan penggajian guru-guru yang berstatus sukarela. Dimana kehadiran komite sekolah telah dapat membantu sekolah untuk penggajian guru-guru sukarela.

\section{2) Kriteria kinerja tenaga pendidikan}

Dalam pengelolaan sumber daya pendidikan dengan indikator peran komite yakni dengan memberikan pertimbangan mengenai kriteria tenaga kependidikan yang dapat diperbantukan di sekolah. Berdasarkan hasil wawancara dengan ketua komite:

Sebagai ketua komite kami turut menyeleksi tenaga-tenaga pendidik yang ingin melamar sebagai guru dan yang pastinya sesuai dengan yang kami butuhkan, kebetulan rata-rata yang mendaftar adalah alumni STKIP Bone dan mereka mahasiswa-mahasiswa saya karena saya juga dosen di STKIP Bone jadi sedikit banyaknya saya sudah mengetahui kualitas mereka, jadi kalau kami sudah melakukan seleksi kami tentukan apakah mereka layak untuk mengajar atau tidak, kalau tidak layak kami tempatkan mereka di bagian tata usaha selagi sekolah membutuhkannya. ${ }^{47}$

Berdasarkan hasil wawancara di atas, diperoleh bahwa peran komite sekolah dalam memberikan pertimbangan terhadap tenaga pendidik ikut secara langsung menyeleksi yang dapat diperbantukan disekolah berjalan dengan baik karena komite sekolah juga dilibatkan menyeleksi dan menentukan apakah mereka layak atau tidak layak untuk dijadikan sebagai tenaga pendidik di sekolah.

Untuk mengabsahkan data, maka peneliti melakukan wawancara kepada kepala sekolah yang menyatakan bahwa:

Dalam pengelolaan sumber daya pendidikan seperti memberi pertimbangan tentang tenaga pendidik dan kependidikan yang diperbantukan di sekolah. Setiap ada tenaga pendidik yang akan diperbantukan di sekolah kami dari pihak sekolah selalu mengkordinasikan dengan komite sekolah karena bagaimanapun komite sekolah adalah partner kami dalam memajukan kualitas sekolah ini kemudian kami bersama-sama menyeleksi dan menentukan apakah layak kita pakai tenaganya atau tidak, dan kebetulan ketua komite juga adalah mantan kepala sekolah di sini jadi kami merasa sangat-sangat terbantu. ${ }^{48}$

Berdasarkan informasi yang diperoleh dari hasil wawancara tersebut, menunjukkan bahwa dalam pengelolaan sumber daya pendidikan dengan indikator kinerja memberikan pertimbangan tentang tenaga kependidikan yang dapat diperbantukan di sekolah sudah dilakukan dengan baik dengan adanya koordinasi antara sekolah dengan komite sekolah dalam penyeleksian calon tenaga kependidikan

\footnotetext{
${ }^{46}$ Dra. A. Sukmawati Andi Zubaer, M.Si, Kepala Sekolah SMA Negeri 19 Bone, Wawancara, Masago.

${ }^{47}$ Drs. H. Andi Zainal Abidin S.Pd., M.Si., M.Kes, Ketua Komite, Wawancara, di Bajoe.

${ }^{48}$ Dra. A. Sukmawati Andi Zubaer, M.Si, Kepala Sekolah SMA Negeri 19 Bone, Wawancara, Masago.
} 
dan turut serta menyeleksi dan menentukan apakah layak atau tidak layak untuk digunakan tenaganya.

\section{3) Kriteria fasilitas pendidikan atau sarana prasarana}

Dalam indikator memberikan pertimbangan mengenai kriteria fasilitas yang dibutuhkan, diperoleh informasi dari hasil wawancara dengan ketua komite sekaitan dengan perannya sebagai pemberi pertimbangan mengatakan bahwa:

Hasil wawancara dengan ketua komite sekolah SMA Negeri 19 Bone menyatakan bahwa:

Masalah mengenai fasilitas sekolah, komite sekolah tidak tinggal berpangku tangan karena kita selalu memikirkan apakah fasilitas ini layak pakai atau tidak jadi kepala sekolah meminta kepada komite untuk merehabilitasi fasilitas itu seperti, apakah ada ruangan kelas yang tidak layak pakai atau tidak, seperti laboratorium dipakai untuk proses pembelejaran itukan tidak cocok karena laboratorium itu dipakai untuk peraktek saja, jadi kami mengarahkan kepala sekolah untuk membikin proposal untuk minta bantuan ruangan kelas. ${ }^{49}$

Berdasarkan hasil wawancara dengan ketua komite sekolah dapat diketahui bahwa kapasitas komite sekolah dalam memberikan pertimbangan mengenai fasilitas yang dibutuhkan sekolah berjalan dengan baik karena komite ikut memantau langsung fasilitas apa yang harus dibenahi kemudian mencari solusinya bersama kepala sekolah agar fasilitas sekolah terpakai sesuai dengan fungsinya.

Untuk mengabsahkan data yang diperoleh maka peneliti melakukan triangulasi dengan wawancara kepada kepala sekolah dengan mengatakan bahwa:

Menyangkut persoalan fasilitas yang dibutuhkan kami dari pihak sekolah meminta rekomendasi kepada komite mari kita bersama-sama melihat fasilitas sekolah kita yang mana perlu dibenahi seperti ruangan kelas yang tidak layak pakai mau tidak mau kita memakai laboraturium untuk pemberian materi pelajaran, maka dari itu kita mencari langkah-langkah apa yang kemudian kita lakukan untuk mencari solusinya. ${ }^{50}$

Makna yang bisa diperoleh dari wawancara kepala sekolah yakni bahwa keberadaan komite di sekolah memiliki kapasitas untuk memberikan rekomendasi atau masukan atau pertimbangan-pertimbangan kepada pihak sekolah, jadi secara tidak lamgsung kebaradaan komite sekolah sangat-sangat membantu karena bagaiamana kemudian komite sekolah ikut langsung memanatau fasilitas sekolah yang mana harus diperbaiki kemudian mencari solusinya bersama-sama.

\section{PENUTUP}

Berdasarkan uraian di atas, maka dapat disimpulkan bahwa peran komite sekolah di SMA Negeri 19 Bone sebagai pemberi pertimbangan, berjalan sesuai dengan prosedur, dengan asumsi bahwa komite sekolah sebagai pemberi pertimbangan (advisory agency) dalam penentuan pelaksanaan kebijakan di satuan pendidikan melibatkan semua unsur, baik dari unsur sekolah ataupun dari luar sekolah seperti orang tua siswa dan masyarakat. Karena dari pelibatan semua unsur komite sekolah, orang tua siswa dan masyarakat akan sangat penting dalam peningkatan kualitas pendidikan di sekolah.

\footnotetext{
${ }^{49}$ Drs. H. Andi Zainal Abidin S.Pd., M.Si., M.Kes, Ketua Komite, Wawancara, di Bajoe.

${ }^{50}$ Dra. A. Sukmawati Andi Zubaer, M.Si, Kepala Sekolah SMA Negeri 19 Bone, Wawancara, Masago.
} 
Penelitian ini diharapkan dapat berkontribusi dan memberikan manfaat kepada pengurus komite sekolah dan kepala sekolah beserta jajaranya yang berada dalam satuan pendidikan, khususnya kepada ketua komite di SMA Negeri 19 Bone agar dapat mengoptimalkan peran-peran komite sekolah agar dapat meningkatkan mutu pendidikan di satuan pendidikan melalui pendidikan yang efektif terencana, terorganisir, dan efesien.

\section{DAFTAR PUSTAKA}

Ardy dan Irham https://radarbone.fajar.co.id/sekretaris-polisikan-ketua-komitesekolah-di-bone/. Diakses: Senin, 12 Februari 2018.

Arikunto, Suharsimi dan Lia Yuliana, Manajemen Pendidikan Yogyakarta: Aditya Media, 2008.

Budimansyah, Dasim, Indikator Kinerja Dewan Pendidikan dan Komite Sekolah. Online: http://.WWw.dikdasmen.depdiknas sentral/dewandik dan komite.go.id) DiaksesTanggal 22 Januari 2012.

Deparetemen Pendidikan Nasional RI, Panduan Umum Dewan Pendidikan dan Komite Sekolah Jakarta: Direktorat Pendidikan Dasar dan Menengah, 2002.

Duhou, Ibtisam Abu, School Based Management, Jakarta: Kencana, 2004.

Haryadi, Yadi, dkk., Pemberdayaan Komite Sekolah: Bahan Pelatihan unt uk Fasilitator Inti Komite Sekolah Tingkat Provinsi dan Kabupaten/Kota pada Modul Penguatan Lembaga Komite Sekolah, Jakarta: Direktorat Jenderal Manajemen Pendidikan Dasar dan Menengah Kegiatan Peningkatan Kegiatan dan Usaha Manajemen Pendidikan Depdiknas RI, 2010.

Hasbullah, Dasar-dasar Ilmu Pendidikan, Cet. II; Jakarta: Raja Grafindo Persada, 2001.

Otonomi Pendidikan (Kebijakan Otonomi Daerah dan Implikasinya Terhadap Penyelenggaraan Pendidikan, Jakarta: Rajawali Grafindo Persada, 2006.

https://www.academia.edu/.people/search?utf8=\%E2\%9C $\% 93 \& q=$ journal + school + coo mitte. Diakses: Jumat, 5 Oktober 2018.

Masduki, Studi Peran Kepala Sekolah dan Komite Sekolah (Online: http://. Www. mbeproject net/mbe59.html)(Diakses Tanggal 22 Januari 2012), h. 3. 
Misbah, M., Peran dan Fungsi Komite Sekolah Dalam Meningkatan Mutu Pendidikan, https://scholar.google.co.id/scholar?start $=40 \& q=j u r n a l+$ komite+sekolah\&hl=id \&as $\mathrm{sdt}=0,5$. Diakses: Senin, 20 November 2017.

Mulyasa, E., Manajemen Berbasis Sekolah Konsep Strategi dan Implementasi, Bandung: Rosdakarya, 2005. , Menjadi Kepala Sekolah Profesional. Dalam Konteks Menyukseskan MBS dan KBK. Bandung: PT Remaja Rosdakarya, 2007.

Mulyono, Manajemen Administrasi dan Organisasi Pendidikan, Jogjakarta: Ar-Ruzz Media, 2010.

Nurkolis, Manajemen Berbasis Sekolah: Teori, Model, dan Aplikasi Jakarta: PT Grasindo, 2005.

Pantjastuti, Sri Renani, dkk., Komite Sekolah, Sejarah dan Prospeknya di Masa Depan Yogyakarta: Hikayat Publishing, 2008.

Pidarta, Made, Manajemen Pendidikan Indonesia, Jakarta: PT Bina Aksara, 2011.

Pidarta, M., Perencanaan Pendidikan Partisipasi dengan Pendekatan Sistem, Jakarta: Rineka Cipta, 1990.

Qomar, Mujamil, Manajemn Pendidikan Islam: Strategi Baru Pengelolaan Lembaga Pendidikan Islam, Jakarta: Erlangga, 2008.

Ramayulis, IImu Pendidikan Islam, Jakarta: Kalam Mulia, 2010.

Raynolds, Larry J., Kiat Sukses Manajemen Berbasis Sekolah; Pedoman bagi Praktisi Pendidikan. terj. Teguh Budiharso, Cet.II; Jakarta: Diva Pustaka, 2005.

Rohiat, Manajemen Sekolah: Teori dasar dan Praktek, Bandung: Refika Aditama, 2008.

Redaksi, https://radarbone.fajar.co.id/astaga-pungutan-komite-bermunculan-di-bone/. Diakses: Senin, 16 Juli 2018.

Salladien, Komite Sekolah dan Kaitannya dengan Implementasi KBK.Makalah Seminar (7 Juli 2004). Fakultas MIPA, Malang: Universitas Negeri Malang, 2004.

Sagala, Syaiful, Administrasi Pendidikan Kontemporer, Bandung: CV Alfabeta, 2008.

Sari, Erna Avriana Purnama, Peran Komite Sekolah Dalam Mendukung Peningkatan Mutu SD Muhammadiyah Wirobrajan 3 Yogyakarta, https://scholar.google.co.id/scholar?start $=40 \& q=$ jurnal+komite + sekolah $\& h l=i d$ \&as $s d t=0,5$. Diakses: Senin, 20 November 2017.

Sholeh, Abdul Rochman, Madrasah dan Pendidikan Anak Bangsa: Visi Misi dan Aksi Jakarta: Raja Grafindo Persada, 2004.

Sidi, Indra Jati, Menuju Masyarakat Belajar: Menggagas Paradigma Baru Pendidikan. Cet. I; Jakarta: LogosWacana Ilmu, 2001.

Sulistyorini dan Muhammad Fathurrohman, Esensi Manajemen Pendidikan Islam: Pengelolaan Lembaga untuk Meningkatkan Kualitas Pendidikan Islam Yogyakarta: Teras, 2014.

Yogyakarta: Teras, 2009.

Suryosubroto, B., Manajemen Pendidikan di Sekolah, Jakarta: PT Rineka Cipta, 2004.

Syaifuddin, Muhammad dkk, Manajemen Sekolah, Depdiknas, 2007

Tim Dosen Administrasi Pendidikan UPI, Manajemen Pendidikan, Cet. IV; Bandung: Alfabeta, 2011.

Wahjosumidjo, Kepemimpinan Kepala Sekolah, Tinjauan Teoritik dan Permasalahannya, Jakarta, Raja Grafindo Persada, 2002. 
Wardiah, Sri, Murniati dan Djailani, 2014. Strategi Komite Sekolah Dalam Peningkatan Mutu Pendidikan di SD Negeri 1 Lhoknga, https://scholar.google.co.id/scholar?start=40\&q=jurnal+komite+sekolah\&hl=id \&as_sdt $=0,5$. Diakses: Senin, 20 November 2017.

\section{Sumber Wawancara}

Drs. H. Andi Zainal Abidin S.Pd., M.Si., M.Kes, Ketua Komite, Wawancara, di Bajoe.

Dra. A. Sukmawati Andi Zubaer, M.Si, Kepala Sekolah SMA Negeri 19 Bone, Wawancara, Masago. 